\title{
STUDY ON SWARMING AND COLONY STRUCTURE OF HARVESTER TERMITE, Anacanthotermes ochraceus CHECKED (BURM) \\ El-Bassiouny,A.R. ${ }^{1}$;H.M.Ahmed ${ }^{1}$ and S.M.Abol-Maaty ${ }^{2}$ 1-Plant Protection Res., Inst. Agric. Res. Center, Dokki, Giza., Egypt \\ 2-Central Lab. of Agricultural Climate, Agric. Res. Center, Dokki, Giza., Egypt
}

\begin{abstract}
This work conducted in Sharkia Governorate, data showed that, the highest number of foraged workers of Anacanthotermes ochraceus (Burm), was found during spring and autumn, 2014, and the lowest was occurred in summer season, the numbers begun increased gradually in January, February, March, April and May, then decreased in Jun, July and August. Workers caste represented $(77.73 \%$ of total colony). Nymphs showed that, the largest number occurred during autumn, and the least was occurred in summer, begun increased in Jan., February, March, April and May, then decreased in Jun-July and Nov-Dec. Nymphs represented (13.36\% of total colony). Soldiers caste were highest during autumn in Sept., then decreased during winter in Nov.- Feb., and began to rise again during March, April and May, while the least number occurred during summer in June-July. Soldiers represented $(7.29 \%$ of total colony), and showed highly rates correlated with the swarmers and the various forms. Swarmers or "alates" were found highly during April and Oct., and the lowest rate occurred in Feb. Crowds of swarmers appeared twice during the year in February, March, April and May, then disappeared and reappeared again in Sept., Oct. and Nov., the swarming were found in spring and autumn seasons and represented (1.69\% of total colony).

Termite castes were abundant in two periods/year in spring and autumn when max., temperature of soil temperature ranged between $\left(25-35^{\circ} \mathrm{C}\right)$, the mini., soil temperature ranged between $\left(13-27^{\circ} \mathrm{C}\right)$, the rainfall were $(0.0,33.0$ and 97.6 $\left.\mathrm{m}^{3} / \mathrm{Inch}^{2}\right)$, and the relative humidity higher than $(70 \%)$, while castes were lower in summer and winter seasons when soil max., temperature were less than $\left(25^{\circ} \mathrm{C}\right)$ and higher than $\left(35^{\circ} \mathrm{C}\right)$, the mini., temperature ranged between $\left(8-26{ }^{\circ} \mathrm{C}\right)$, the rainfall higher than $\left(100 \mathrm{~m}^{3} / \mathrm{Inch}^{2}\right)$, and the relative humidity less than $(70 \%)$.

Crowds of swarmers avoid time rainfall and appeared profusely in the periods after the rain when the weather is warm and the soil is moist, the homeowners begun to see winged termites emerge in large numbers inside their home on the soil surface.

Statistical analysis showed no significant for tested factors, while were significant with R.H. was the main reason for this effect.

Keywords:Swarming; Anacanthotermes ochraceus; Colony structure; Workers caste; Nymphs caste; Soldiers caste; Winged caste; Climate effect; Caste composition.
\end{abstract}

\section{INTRODUCTION}

Subterranean termites are the single greatest economic pest in Egypt. These termites cause damage to homes, historical structures, and commercial buildings. In addition to buildings, termites also consume valuable books, documents and photographs. Subterranean termites are 
social insects; this means that they live in family groups called colonies. Social insects are different from other insects (grasshoppers, cockroaches, or beetles) because each termite in the colony performs a specific job that benefits the colony as a whole. In the termite colony an entire group or caste of termites is responsible for feeding their parents and siblings, while another caste is responsible for reproduction. Because of this division of labor, the colony of individuals functions as a single animal. The following is a description of how a subterranean termite colony becomes established and how the different castes interact and communicate as the colony grows. Foraging activity and special distribution patterns of subterranean termite are commonly assessed using traps laid out on the ground or partially buried. Several type of traps have been used most frequently wooden stakes (Jones 1990), toilet paper rolls (Lafage et al. 1973), corrugated card-board rolls (Lafage et al. 1983, El-Sebay 1991, El-Bassiouny 2001 and Ahmed 2003). Such methods of trapping which carried out in the same arid land by the absence of grass cover have given good results such as obtained in Egypt (Said 1979) and in Saudi Arabia (Badawi et al. 1984).

The present work was carried out in Sharkia Governorate to study the climate change impact (temperatures, $\mathrm{RH}$ and rain) on the swarming and colony structure of Anacanthotermes ochraceus (Burm).

\section{MATERIALS AND METHODS}

\section{Exploring colonies in tested area:}

Experiments were carried out in Sangha village, Kafr Saqr, Sharkia Governorate. An area of about $\left(200 \mathrm{~m}^{2}\right)$ heavily infested by subterranean termite $A$. ochraceus, was chosen for this study. 100 of PVC traps were randomly distributed a month before treatment in infested area to detect and determined 10 infested localities.

Experiments:

The experiment was begun in January to December 2014. The infested area were cleaned from some superficial, any source of cellulose and debris and removed to prevent any nutrient interferences with the used traps. The area was leveled and irrigated then left to full dry. Fifty holes were digged with small axe, where, the holes were arranged in 10 rows and 5 column, the distance between holes was $2 \mathrm{~m}^{2}$ and the hole depth was $12 \mathrm{~cm}$. P.V.C. traps were implanted to be tested and it consists of cylindrical container from a thermoplastic polymer with $12 \mathrm{~cm}$ in length and $7 \mathrm{~cm}$ in diameter, the container was holes by 12 apertures in which was inserted a corrugated cardboard roll $10 \mathrm{~cm}$ length and $7 \mathrm{~cm}$ in diameter. All traps were wetted with $300 \mathrm{ml}$ water and distributed in holes of the tested area and arranged as 10 traps in column and 5 in row, each trap was subtended ( 8 $\mathrm{m}^{2}$ ) in each directions east, west, north and south. Trap was numbered and buried to appear equal to the surface of soil.

Traps were collected monthly and replaced by new ones. Infested traps kept in tightly closed plastic bags, then transported to the laboratory for 
inspection. Castes were separated by using small fine brush and counted. Numbers calculated on average and regulated to correct numbers

Meteorological data source:

Meteorological data (temperatures, rain and relative humidity) were obtained from Central Lab., of Agricultural Climate, Agric., Res., Center, Dokki, Giza., Egypt. Data were calculated as mean of months throughout 2014.

\section{Statistical analysis:}

Tested factors were estimated based on correlation " $r$ " and regression "b" coefficient in SAS program, (SAS Institute, 1988).

\section{RESULTS AND DISCUSSION}

\section{Swarming seasons and colony structure of $A$. ochraceus: Adult workers caste:}

Data presented in Table (1), show that the maximum number of foraged $A$. ochraceus, workers was (3533 individuals) during May 2014, and the mini., number was occurred in December (1146 individuals), the numbers begun increased gradually in Jan., Feb., March, April and May, (1236, 1345, 2497, 3075 and 3533 individuals, respectively), then decreased in Jun, July and August (1180, 1645 and 2033 individuals, respectively). The total numbers of workers caste were (24347 individuals/year) represented $(77.73$ $\%)$ in relation to the overall size of the colony fig.,(1).

The high numbers of workers may have been due to they do most of the colony works. It is worth mentioning that, the adult worker metamorphoses start from the $3^{\text {rd }}-6^{\text {th }}$ stage, and dominated by color "white yellowish".

Rizk et al. (1985), the workers population curve of $P$. hypostoma, has two peaks during February/March and August/September, and two bottoms during May/July and November/December. El-Dossoki et al. (2009): mentioned that the maximum number of foraged workers was occurred during December and January 1995, 1996 respectively, but the minimum number was at June in both years.

Nymphs caste (Small workers):

The $1^{\text {st }}$ and $2^{\text {nd }}$ stages of termites called nymphs or small workers and dominated by color "pure white".

Data presented in Table (1) show that the largest number of foraged $A$. ochraceus, nymphs was (563 individuals) occurred during Sept., and the least number was occurred in Jun (148 individuals), the numbers begun increased gradually in Jan., Feb., March, April and May, (214, 302, 314, 530 and 532 individuals, respectively), then decreased in July, Nov., and Dec., (224, 286 and 239 individuals, respectively). The total numbers were (4185 individuals/year) represented $(13.36 \%)$ in relation to the overall size of the colony fig.,(1).

The percentages of adult worker + nymphs (small workers) showed $(91.09 \%)$ for colony size. 
Rizk et al. (1985) who found that, the $P$. hypostoma, nymphs were emerged and short period after swarming and the larval abundance occurred during May to August. El-Dossoki et al. (2009): The largest number of first and second nymphal instars of Psammotermes hypostoma (Desn) occurred during February, March and September 1995, while the nymphs were found in September and October 1996, but the lowest number occurred during June in both years.

\section{Soldiers caste:}

The largest number of soldiers caste occurred (315 individuals) during Sept., and then decreased during Nov. to Feb. (139, 185, 123 and 136 respectively), Then it began to rise again during March, April and May (236, 242 and 205 soldiers respectively). While the least number occurred during June and July (123 and 124 soldiers). Soldiers were highly rates correlated with the swarming season and the various forms (fig., 1). The total numbers of soldiers caste were (2257 individuals/year) represented (7.29\%) in relation to the overall size of the colony fig.,(1).

Rizk et al. (1985), found that, the total numbers of $P$. hypostoma, soldiers were (2257 individuals/year) represented $(7.29 \%)$ positively correlated with the total number of the various forms, and the soil moisture had affected the flight of Psammotermes hypostoma (Desn.) and colonies in the dry regions could not fly. El-Dossoki et al. (2009): mentioned that, the largest number of $P$. hypostoma soldiers occurred during October, November and December in 1995, while it occurred during January, March and December in 1996 while the least number occurred during June 1995 and 1996.

\section{Winged caste (Swarmers):}

Data in Table (1), show that the high rates of swarmers, A. ochraceus, were (121 and 114 individuals) found during April and Oct. 2014, and the low rate occurred in Feb. (35 individuals).

Crowds of swarmers appeared twice during the year in Feb., March, April and May, (35, 85, 121 and 76 individuals, respectively), then disappeared and reappeared again in Sept., Oct. and Nov. (43, 114 and 56 individuals, respectively). The most seasonal swarming was found during spring and autumn seasons. The total numbers of swarmers caste were (530 individuals/year) represented (1.69 \%) in relation to the size of colony fig.,(1). This caste has many names winged caste, swarmers, alates, reproductive caste and Sexual reproductive.

Rizk et al. (1985), stated that the termite of Psammotermes hypostoma (Desn.) has two oviposition periods, the eggs are found in nests (March/April and July/September), larvae were found all over the year except from May to August, Nymphs were found after swarming and its shortly. Workers were found all over the year. The larvae having a population curve with two peaks during February/March and August/September, and two bottoms during May/July and November/December. Soldiers are found all over the year with their number positively correlated with the total number of all different forms. Salman et al. (1987), found that the foraging activity of sand termites, Psammotermes hypostoma (Desn.) was high during spring and summer and low during winter foraging activity was reduced immediately after swarming. 
El-Sebay (1993), reported that the caste composition of Anacanthotermes ochraceus (Burm.) were 63, 33, 3 and $0.6 \%$ for workers, larvae, soldiers and alates, respectively. This ratio mostly differs according to season of year. ElBassiouny, (2001), in study on sand termite, Psammotermes hybostoma (Desnuax), throughout two successive years of 1995 and 1996, he found that, the adult workers of termite were abundant during winter and autumn seasons. The small workers ( $1^{\text {st }}$ and $2^{\text {nd }}$ nymphal stages) and soldiers were abundant during the winter and reduced during summer season. On the other hand, swarmers or winged castes (alates) were occurred during autumn and summer months. The population of workers represented the highest percentages from the total numbers of gallery, followed by soldiers, nymphs and alates. El-Dossoki et al. (2009), mentioned that, Alates of $P$. hypostoma was found from September to December 1995 while during January to March and from October to December in 1996.

Climate effect on caste composition of $A$. ochraceus:

The termite castes adult workers, nymphs, soldiers and alates were more abundant during two periods in year in spring and autumn when the max., soil temperature ranged between $\left(25-35^{\circ} \mathrm{C}\right)$, the mini., soil temperature ranged between $\left(13-27^{\circ} \mathrm{C}\right)$, the rainfall were $\left(0.0,33.0\right.$ and $\left.97.6 \mathrm{~m}^{3} / \mathrm{Inch}^{2}\right)$, and the relative humidity higher than $(70 \%)$. While castes were lower in summer and winter seasons when the soil temperature were less than (25 $\left.{ }^{\circ} \mathrm{C}\right)$ and higher than $\left(35^{\circ} \mathrm{C}\right)$, the mini., temperature ranged between $(8-26$ $\left.{ }^{\circ} \mathrm{C}\right)$, the rainfall higher than $(1$

$\left.00 \mathrm{~m}^{3} / \mathrm{Inch}^{2}\right)$, and the relative humidity less than (70\%).

Table (1): Swarming and foraging population average of subterranean termite $A$. ochraceus affected by climate at Sharkia Governorate

\begin{tabular}{|c|c|c|c|c|c|c|c|c|c|}
\hline \multirow[b]{3}{*}{ Months } & \multicolumn{9}{|c|}{ Caste composition and climate } \\
\hline & \multicolumn{4}{|c|}{ Caste forms } & \multirow[b]{2}{*}{$\begin{array}{l}\text { Total } \\
\text { colony }\end{array}$} & \multicolumn{4}{|c|}{ Climate } \\
\hline & Workers & Nymphs & Soldiers & Winged & & $\begin{array}{l}\text { Max. } \\
\text { Temp. }\end{array}$ & $\begin{array}{l}\text { Mini. } \\
\text { Temp. }\end{array}$ & $\underset{\mathrm{m}^{3} / \mathrm{Inch}_{2}^{\text {Rain }}}{ }$ & R. H. \\
\hline Jan. & 1236 & 214 & 123 & 0 & 1573 & 21.8 & 15.7 & 105.4 & 65.1 \\
\hline Feb. & 1345 & 302 & 136 & 35 & 1818 & 28.0 & 17.3 & 194.6 & 78.3 \\
\hline Mar. & 2497 & 314 & 236 & 85 & 3132 & 28.5 & 19.1 & 97.6 & 83.7 \\
\hline Apr. & 3075 & 530 & 242 & 121 & 3968 & 31.0 & 26.0 & 33.0 & 80.0 \\
\hline May & 3533 & 532 & 205 & 76 & 4346 & 35.1 & 27.5 & 0 & 76.0 \\
\hline June & 1180 & 148 & 105 & 0 & 1433 & 38.1 & 26.0 & 0 & 68.7 \\
\hline July & 1645 & 224 & 124 & 0 & 1993 & 37.0 & 22.0 & 0 & 63.1 \\
\hline Aug. & 2033 & 386 & 209 & 0 & 2628 & 36.6 & 18.5 & 0 & 70.2 \\
\hline Sep. & 3200 & 563 & 315 & 43 & 4121 & 24.5 & 17.1 & 0 & 72.0 \\
\hline Oct. & 2218 & 447 & 238 & 114 & 3017 & 25.2 & 13.0 & 0 & 78.7 \\
\hline Nov. & 1239 & 286 & 139 & 56 & 1720 & 24.5 & 12.3 & 187.2 & 70.0 \\
\hline Dec. & 1146 & 239 & 185 & 0 & 1570 & 22.1 & 08.9 & 295.6 & 68.0 \\
\hline \begin{tabular}{|l} 
Total \\
\end{tabular} & 24347 & 4185 & 2257 & 530 & \multirow{2}{*}{31319} & - & - & - & - \\
\hline Total $\%$ & 77.73 & 13.36 & 7.29 & 1.69 & & - & - & - & - \\
\hline \multicolumn{10}{|c|}{ Common statistics } \\
\hline \multirow{2}{*}{ Factors } & \multicolumn{4}{|c|}{ Simple correlation "r" coefficients } & & \multicolumn{4}{|c|}{ Simple regression "b" coefficients } \\
\hline & Workers & Nymphs & Soldiers & Winged & & Workers & Nymphs & Soldiers & Winged \\
\hline Max. Temp. & 0.17858 & -0.0349 & -0.2172 & -0.1453 & & 0.2589 & 0.3221 & 0.3963 & 0.2305 \\
\hline Mini. Temp. & 0.49278 & 0.22991 & -0.0329 & 0.16940 & & 0.3208 & 0.7793 & 0.5965 & 0.6617 \\
\hline Rain $\mathrm{m}^{3} / \mathrm{Inch}^{2}$ & -0.5626 & -0.4156 & -0.2904 & -0.2095 & & 0.1136 & 0.1317 & 0.0846 & 0.2242 \\
\hline R. H. & 0.54565 & 0.53805 & 0.53848 & 0.82912 & & 0.1326 & 0.1515 & 0.0942 & 0.0055 \\
\hline
\end{tabular}


Fig. (1): Cast composition\% of A. ochraceus (Burm)

Workers (77.73\%)

Nymphs (13.36\%)

Soldiers (7.29\%)

Winged (1.69\%)

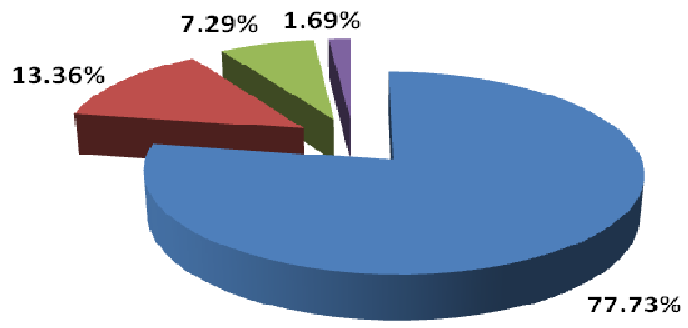

During the daylight hours of the spring months (March-May) and autumn (Sept.-Nov.) in Sharkia Governorate, the homeowners begun to see winged termites emerge in large numbers inside their home on the soil surface. These are the subterranean termite swarmers (new termite kings and queens), that must leave their parent colony in order to mate and establish new colonies of their own.

The swarmers pair fly short distances and then land in a suitable place to start a colony. Then remove of the wings by contact with soil granules and the royal pair starts excavating a small chamber in soft soil.

Crowds of swarmers avoid time rainfall and appeared profusely in the periods after the rain when the weather is warm and the soil is moist.

In this work, the separated swarmers were dark brown found with wings or wings removed; this result was agreement with El-Bassiouny, (2001).

Swarming is the termite method of dispersal and establishing new colonies. Subterranean swarmers emerge from the colonies at certain times of the year when conditions are suitable. Swarming phenomenon were occurred during the daylight hours on warm days following a rainfall, the swarmers are attracted to light (photopositive), so if they emerge in the home will be seen flying to windowsills and open doors.

Kofoid (1934), mentioned that the foraging activity was low when relative humidity was high. Kemp (1955), emphasized that, when the relative humidity was high the foraging activity was low. Bodot (1967), reported that rainfall increased foraging activity and vice versa in dry season. Among the factors that influence foraging were: soil temperature, relative humidity, rainfall, caste composition, nutrients, colony density, and nutritional status of the colony. Harverty et al. (1975), in USA, studied the seasonal activity of the subterranean termites, Heterotermes areus (Snyder), he reported that the foraging intensity was regulated according the fluctuation of the temperature and rainfall. La Fage et al. (1975), in USA, studied the climatic factors correlated with the foraging behaviour of a desert subterranean termite, Ganthomitermes perplexus (Bnks). They showed that foraging activity was 
limited by upper level $(10-5 \mathrm{~cm})$ soil temperatures within the range $9-49{ }^{\circ} \mathrm{C}$. Periodic rises in soil moisture resulting from rainfall increased foraging activity, while in South Africa, he mentioned that, the diurnal and seasonal foraging of Hodotermes mossambicus (Hagen) appear to be large controlling by soil surface temperature. Ohiagu (1979), in Nigeria, stated that low temperature limited the foraging activity of termites, Trinervitermes geninatus, in a desert environment in grassland. Said (1979), in Egypt, showed that the foraging activity of $A$. ochraceus was found to be positively correlated with the corresponding weekly mean temperature. Abdel-Wahab et al. (1983), in Egypt, reported that, the relation between termite activity and temperature and relative humidity revealed that $60 \%$ of the Psammotermes hypostoma (Desn.) activity were attributed to the meteorological variables, the mini., relative humidity seems to be the most effective variable followed by the maximum temperature. Salman et al. (1987), in Egypt, stated that, the climatic variation (mini., and max., air temperature) at $5 \mathrm{~cm}$ above the soil surface accounted for $73 \%$ of the termite activity of $P$. hybostoma, with mini., air temperature having the greatest effect.

Data in table (1), showed no significant for tested factors, while were significant for the relative humidity $(\mathrm{RH})$ was the main reason for this effect.

\section{Summary and target:}

Data showed that, the highest number of foraged termites Anacanthotermes ochraceus (Burm), was found through the rain wet months during the year and disappeared during the hot summer months, this means that the surface activity increased in the rain months when the subsurface activity is decreased. The swarmers were appear after rainfall directly. Workers were the highest number followed by nymphs, soldiers and swarmer (alates), respectively. The research aims to find out seasonal periods termites for easy selection periods of control against castes active in destruction and regeneration of colony.

\section{REFERENCES}

Abdel-Wahab, A.M.; M.R. Rizk; M.H. Hussin; T.K. Abd El-Raof and M.S. ElTaib (1983): Surface activity of sand termites Psammotemes hypostoma Desneux in Aswan. Assuit J. Agric. Sec., 14(3): 99-108.

Ahmed, H.M. (2003): Ecological and control studies on subterranean termites under Fayoum conditions. Ph. D. Thesis Fac. Agric. Fayoum, Cairo University. pp.148

Badawi, A.; A. A. Faragallah and A. Dabbour (1984): Population studies of some species of termites in Al-Kharj Oasis, Central Region of Soudi Arabia. Z. F. angew. Entomol. 97: 253-261.

Bodot, P. (1967): Cycles soissnoiers d'activite collective des. Termites des savanes, de Basse cared'Ivoire. Insects Socioux, 14: 359-388.

El-Bassiouny, A.R. (2001): A study on the ecology and biological control of subterranean termites. M.sc.Thesis, Fac. Agric.Al-Azhar Univ. pp. 145. 
El-Dossoki, S.A; S.M. El-Awady; Y. El-Sebay and A.R. El-Bassiouny (2009): Studies on some ecological aspects of sand termite, Psammotermes hypostoma (Desn.) at Ismailia Governorate. J. Agric. Res., 87 (1): 1-12

El-Sebay, Y. (1991): Amodified trap for El-Sebay subterranean termite. Fourth Arab Congress of plant protec. Cairo.1-5.Dec.,1991pp.245-247.

El-Sebay, Y. (1993): Ecological studies on the harvester termites Anacanthotermes ochraceus (Burm.) in Egypt. Assuit J. Agric. Sci., 24 (4) 35- 47.

Harverty, M.I.; J.P. Lafag and W.L. Nutting (1975): Seasonal activity and environmental control of foraging of the subterranean termites, Heterotermes aureus (Snyder). Environ. Entomol. 4: 105-109.

Jones, S. C. (1990): Delineation of Heterotermes aureus (Isoptera : Rhinotemitidae) foraging territories in a sonoran desert grassaland. Environ. Entomol., 19 (4): 1047-1054.

Kemp, P.B. (1955): The termites of northeastern tanganyika, their distribution and biology. Bulletin of Entomological Research, 46: 113-135.

Kofoid, C.A. (1934): Climatic factors affecting the local occurrence of termites and their geographical distribution, in Kofod, C. A. (Ed.), "Temites and Termite Control". California Univ. Press, $2^{\text {nd }}$ Ed., 42-49.

Lafage, J.P., M.I. Harverty and W.L. Nutting (1975): Environmental factors correlated with the foraging behavior of the desert subterranean termite, Ganthomitemes perplexur (Bankd) (Isoptera : Lemrmitidae). Sociobiology, 2(3): 155-167.

Lafage, J.P., Nutting, W.L. and Haverty, M.I. (1973): Desert subterranean termites : a method for studying foraging behaviour. Environ. Entomol., (2): 954-956.

Lafage, J.P., Su, N.Y.; Jones, M.J., and Esenther, R. (1983): A rapid method for collecting large numbers of subterranean termites from wood. Sociobiolgy (7): 305-309.

Ohiagu, C.E. (1979): A quantitative study of seasonal foraging by the grass harvesting termite, Trinervitermes geninatus (Wasmann) (Isoptera: Nosuitermitidae) in southern Guinwa savanna, Mokwa, Nigeria. Oecologia (Berlin), 40: 179-188.

Rizk, M.M.; El-Sayed, A.R.; Ali, A.M and Eraky, S.A. (1985): Flight activity and annual caste fluctuation of sand termite Psammotermes hybostoma (Desneux) in western desert-Egypt. Assuit. J. Agric. 16 (2): 137-148.

Said, W.A., (1979): Ecological and toxicological studies on Fam. Hodotermitidae M.Sc. Thesis Fac. of Agric. Ain Shams Univ. pp. 128.

Salman, A.G.; Morsy, A.A. and Sayed, A.A., (1987): Foraging activity of the sand termite Psammotermes hybostoma (Desneux) in the New Valley, Egypt. Assuit. J. Agric. Sci. 18 (4) : 84-90.

SAS Institute (1988): SAS user's guide: Statistics. SAS Institute, Cary, N.C. 


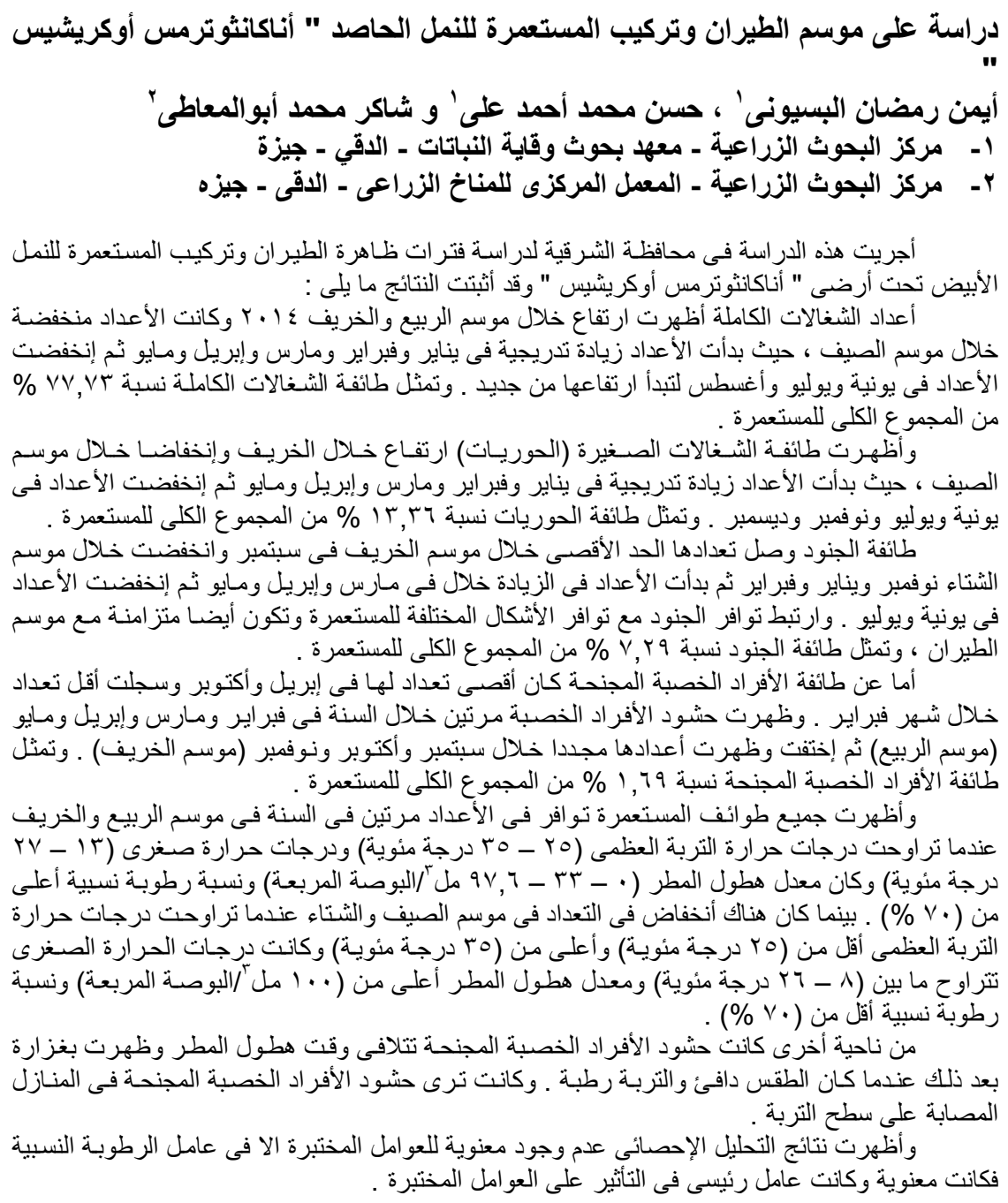

